\title{
The study of travel social marketing based on mobile Internet
}

\author{
Xin Li, Yu Cao, Yilei Lu, Pei Yu, Xiaoli Tang \\ Xin Li, Wuhan Donghu University, China \\ Yu Cao (Corresponding Author), Wuhan Donghu University, Associate professor, China \\ Yilei Lu, Wuhan Donghu University, China \\ Pei Yu, Wuhan Donghu University, China \\ Xiaoli Tang, Wuhan Donghu University, China
}

Keywords: Mobile Internet; Travel social marketing; Travel market; Mobile Internet applications

\begin{abstract}
In the field of marketing of tourism products, the rapid development of powerful and innovative social marketing model, which has changed the traditional marketing model, Resource information of tourism products through the consumer experience, to use socialmedia for publishing and dissemination, can accelerate the tourism product enterprise brand concept popularization, and influence and promote consumer consumption decision, a catalytic role for the sustainable development of tourism industry.
\end{abstract}

\section{OVERVIEW OF MOBILE INTERNET APPLICATIONS}

The basic concept of mobile Internet. Mobile Internet (Mobile Internet, referred to as MI) is a mobile communications and the Internet combine the two into one. It is through the intelligent mobile terminal in a mobile radio communications system based on. Smart phones, tablet PCs, e-books, MID and other terminal layer using the software (operating system, middleware, database and security software, etc.) to get the application layer (recreational classes, tools, media-business finance and economics, etc.) and services. Terminals, software, and application of these three points in a line constitute the mobile Internet. Mobile Internet allows users anytime, anywhere access to Internet, or access to information, or for business, entertainment, and other network services.

Mobile Internet application status in the travel industry. By the end of 2013, the number of Internet users in China reached 618 million, of which there are 500 million mobile phone users number, accounting for $80 \%$ of the total. 2014 the scale of China's mobile Internet users reached 750 million, with this trend, mobile Internet subscribers will continue to maintain rapid growth. Mobile Internet applications will become increasingly important (see Table I and Figure 1).

"34th Statistical Report on Internet Development in China," China Internet Network Information Center (CNNIC) On July 21, 2014 release of the report, as of June 2014, Chinese netizens reached 632 million, representing an increase by the end of 20131442 million, Internet penetration rate of 46.9\%. Internet development focus to the "in-depth" transition from "extensive", the network application users profoundly change lives. 
Table 1 2011-2014 Internet-based data

\begin{tabular}{|l|l|l|l|l|}
\hline $\begin{array}{l}\text { Investigation } \\
\text { time }\end{array}$ & $\begin{array}{l}\text { The number } \\
\text { of Internet } \\
\text { users[millio } \\
\mathrm{n} \text { ] }\end{array}$ & $\begin{array}{l}\text { The number } \\
\text { of } \\
\text { sites[million } \\
\text { ] }\end{array}$ & $\begin{array}{l}\text { Number of } \\
\text { mobile } \\
\text { phone } \\
\text { users[millio } \\
\mathrm{n} \text { ] }\end{array}$ & $\begin{array}{l}\text { Number of } \\
\text { domain } \\
\text { names[mill } \\
\text { ion] }\end{array}$ \\
\hline June 2011 & 485 & 1.83 & 260 & 7.86 \\
\hline $\begin{array}{l}\text { December } \\
2011\end{array}$ & 513 & 2.30 & 318 & 7.75 \\
\hline June 2012 & 538 & 2.50 & 364 & 8.73 \\
\hline $\begin{array}{l}\text { December } \\
2012\end{array}$ & 564 & 2.68 & 420 & 13.41 \\
\hline June 2013 & 591 & 2.94 & 464 & 14.70 \\
\hline $\begin{array}{l}\text { December } \\
2013\end{array}$ & 618 & 3.20 & 500 & 18.44 \\
\hline June 2014 & 632 & 2.73 & 527 & 19.15 \\
\hline
\end{tabular}

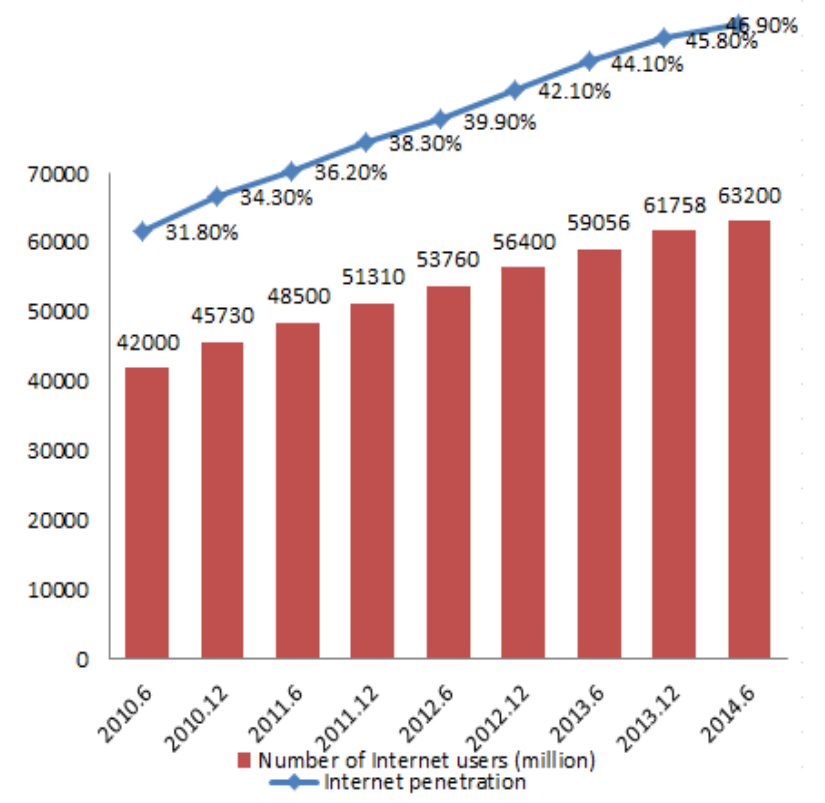

Figure. 1 The scale of Chinese Internet users and Internet penetration

Until June 2014, the scale of China's Internet users reached 632 million, half a million people in a total of 1442 new users. Internet penetration rate was 46.9\%. As of the end of December 2013, the Chinese mainland's 31 provinces (municipalities) in size over ten million Internet users reached 23 provinces. Internet penetration Hubei, Chongqing, Qinghai and other nine provinces is higher than the global average. Hubei province's total number of Internet users reached 2129 million, ranking seventh in the country, only Wuhan City alone more than 70,000 sites for the record.

It is because of the huge population of mobile Internet users, more and more travel companies have seen the opportunities, gave birth to a new form of tourism services, widening the traditional tourism marketing channels to promote the rapid development of Tours. Mobile Internet applications in tourism industry have become after the traditional travel agency services, online travel services form a third new tourism services. Mobile travel services model also attempts to bring the mobile 
Internet marketing tourism industry to introduce new ideas, relying on smartphones travel planning, booking and share travel experiences, etc., the development of customized service class scenic city or APP, AR (Enhanced technology in all aspects of reality), LBS, HTML5, etc. You can say that mobile Internet has changed the travel industry in walking. Visitors can through the smart phone, check the route, check attractions, check the food, and through mobile phone camera, micro-blog to share their travel experiences. Undoubtedly, this interaction can be made between the scenic and tourist more intimacy, which is officially one of the major scenic values of mobile marketing. When tourists arrive one place, opening mobile Internet applications, the hotel location near restaurants and a range of entertainment information (price, containment, and discount) should be pushed up. Not only that, faced with unexpected situations, but also to have a good emergency measures. Such as rain, relevant information immediately pushed to users of indoor activities, appropriate gift coupon. This will not only win the goodwill of the user, but also the businesses sell out, do both. In the future, we will become more wisdom of travel. The reason why we say that the tourism industry has a natural and mobile Internet links also lies here.

\section{TRAVEL SOCIAL MARKETING}

The concept of social marketing. Social media marketing is the use of social networking, online community, blog, Wikipedia or other Internet Sites and media to a way of marketing, sales, public relations and customer service, handling maintenance and pioneering. Is a closely linked with social media marketing campaigns. You can say that customer relationship marketing network society is the social platform's core mutual dialogue in the network above user to establish a relationship network. Characteristics of social marketing networks to use dialogue, and establish a good image of the product in the dialogue and the promotion of the use of the product out of this dialogue in order to achieve marketing purposes. Social marketing has gone through a few years, but now when it comes to social marketing, most people's understanding of the operations are microblogging turn often get a lot of feedback, which is the use of social media marketing microblogging successful expression. General social media marketing tools including forums, microblogging, blog, SNS community, pictures and video sharing.

The characteristics of social marketing. User generated content:Enterprises to market-oriented, the market should be based on the user experience as the standard. So in web2.0 environment how to mobilize users to participate in the development of new products, business services and other business operations as well? Network marketing social media sites have mainly refers to the comprehensive nature of the network, the site most of the content provided voluntarily by users (UGC), and the user and the site there is no direct employment relationship. It can be said UGC mode allows users to become more involved in business in the past. For product users can provide their own ideas: Ctrip such as in the tourism industry, an important APP, first at the site and the construction of information and work hard, try to add valuable information to the user-supplied Ctrip products, provided travel-related businesses.

And "Hotel Reviews", the Ctrip now have 230,000 responses, information contained in these responses is very quality. Because Ctrip online, consumers must be scheduled through Ctrip can leave comments. By hotel reviews, customers can get real, comprehensive, timely feedback messages. When people are willing to take the initiative to express their thinking, as these companies only need to mobilize the enthusiasm of people willing to express, then UGC model can provide a lot of useful ideas and customer feedback. This is a successful social media marketing. 
Traditional marketing, advertising is bombarded with information, the information indoctrination. This hysterical marketing, will scare away customers. Moreover in the Internet environment. Internet users are quite easy to escape. We need dialogue, and users can be said that the market Web2.0 is the exchange of information under the "markets are conversations". Especially social media marketing allows businesses and users communicate faster and more convenient, more time-sensitive. Involved in marketing through dialogue, the advantage is more close to the people, businesses and consumers have emotional level exchanges, users more easily find the channel feedback. In this context most people's attention is the micro-channel public platform, micro-channel was originally an own billion users of APP, develop the value of their users to add more quality content for this new platform, together with the original emotional foundation, so that micro-channel since the use of public accounts platform media activities more smoothly. Since the media event for media is simply many sexual activities, businesses apply for public micro-channel service number, through secondary development, docking micro-channel cloud marketing system for members to show to the user. Such as micro official website, micro members push micro, micro-payments, micro activities, micro registration, micro-sharing, micro business cards. This has become a mainstream online line under micro-channel interactive marketing. This marketing approach based on emotional bond, plus word of mouth circle of friends, it may form a "virus" in the form of communication, create a positive, good brand image.

Open, transparent and innovation:Web2.0 user is from the media, they are free to comment related content. China's enterprises need a mind and strategy: to create an open and transparent business model innovation (Open Business Models), to update the attitude toward the world. At this point there is the United States doing well at IBM's Linux, the company through the joint assistance of Internet users, content sharing, and promote its rapid escalation, it reliable and popular achievements of Linux. Enterprise and Internet users through direct dialogue, the director sets the public, bringing together the views of users to create their own products. If China can have a more open and transparent and innovative company, future progress will be unlimited. Look forward to more Chinese enterprises brave open-minded, to engage in dialogue.

Social media marketing is based on the mobile Internet applications social marketing, social marketing for the mobile Internet, it is like water in the presence of fish. With mobile Internet social marketing is like a menace. The mobile company's "Hubei Hui better", the longest, the integration of the scope of the largest and most widely affects resources, enhance the brand's most significant influence on the Group's largest customer, market-driven integrated communications campaign that is both successful combined model.

\section{MOBILE INTERNET APPLICATIONS IN TOURISM IN SOCIAL MARKETING}

Mobile Internet applications is an inexpensive, the most widely used technology, the basic technology of modern tourism for the public service. It's very large user base will be the travel industry marketing battleground. "China Tourism Statistics Bulletin 2013" shows that in 2013 the number of domestic tourist trips to 3.262 billion revenue amounted to 2.627612 trillion yuan, 129 million tourist arrivals for passengers, international tourism (foreign exchange) revenue $\$ 51.664$ billion, China's outbound The number of passengers reached 98,185,200, the annual tourism revenue 2.95 trillion yuan. Chinese online travel market in 2013 exceeded 250 billion yuan deal size. Such an enormous potential market, it is accompanied by the development of the Internet and the emergence of e-commerce technology, the popularity of the Internet makes the unprecedented growth of 
e-commerce, it will people's consumption habits, habits transferred from the line to line. According to the survey, the development of mobile Internet applications makes the phone to book one of the most important online travel reservation form products. Some tourists in the tourist areas and the needs of traveling temporarily generated: such reservation, car rental, tickets, reservations, itineraries change and so can be resolved by phone. This also solves the inevitable conflict between the tourism product and tourism consumer demand.

\section{CONCLUSIONS}

Today, social media marketing and mobile Internet combined with the momentum is already formidable, both of which it is most in need of creative talent with customers, build relationships with the public, to create profits. If domestic enterprises cannot properly convey the social media guide for the development of useful business information, then we will be more low level of marketing. Therefore, we should recognize the role in promoting the tourism industry, the mobile Internet, in social marketing model, active and innovative development of tourism, do not let a reluctant tourism development. Social progress and civilization is the development of the tourism industry of tomorrow will be more brilliant.

\section{References}

[1] J.J. Lv: Arts education functions of public cultural institutions to explore - Beijing China Film Association, "old movie Salon" Case [D] Beijing: Central Ethnic University, 2012(In Chinese)

[2] Y.H. Yang: Exploring corporate social marketing model based SICAS model [J] E-commerce, 2011(In Chinese)

[3]Y. Li: Problems of enterprise microblogging marketing of conduct [D] Beijing: Foreign Economic and Trade University, 14-16, 2013(In Chinese)

[4]Q.R. Shen: From Social Media Marketing watching Hunan Satellite TV mobile interactive social applications "hula" [J] News Research Guide, (9): 43-46, 2013(In Chinese)

[5]Y.L. Zhao: China's mobile phone users online information behavior influencing factors [A], Tenth Cross-Strait Academic Library and Information Science Symposium [C], 647-652, 2010(In Chinese)

[6] H.Z. You: Evolution of social media, Beijing University of Posts and Telecommunications, [D]2012(In Chinese)

[7]R. Xiao: Effect of on social media, educational theory and practice[J],the 30 phase of ,2011(In Chinese)

[8]G.H.Yang: The new marketing mode innovation: tourism events and news transmission[J], modern media, 12,2009(In Chinese)

[9]Z. Wang: Research on mobile internet marketing strategy based on., [J]2,2013(In Chinese)

[10]J. Wu,L.S. Wang and X.M. Wang: In-depth appication of electronic commerce assistedtake-off [J] shopping tourism, modemization, the18phase of , 2007(In Chinese) 